\title{
Effects of Sediment Trace Metals and Particle Size on the Community Structure of Epibenthic Seagrass Fauna near a Lead Smelter, South Australia
}

\author{
T. J. Ward ${ }^{1}$ and P. C. Young ${ }^{2}$ \\ Division of Fisheries Research, CSIRO Marine Laboratories \\ ${ }^{1}$ Private Bag 2, Glen Osmond, S. A. 5064, Australia \\ ${ }^{2}$ P. O. Box 21, Cronulla, N. S. W. 2230, Australia
}

\begin{abstract}
The vagile epibenthic fauna of seagrass beds (Zostera mucronata, Posidonia australis, $P$. sinuosa) and bare intertidal muds have been studied near a large lead smelter. Collections were made in winter and summer. The community parameters species richness, species composition and the abundance of species have been used to investigate the distribution of fauna in the study area. Four independent patterns were discerned in the faunal distributions. These patterns clearly delineated the intertidal from the subtidal faunas, and the 2 most significant could be correlated, in the subtidal fauna, with certain sediment parameters previously measured. The first pattern (shown by 20 common, mostly fish, species) described decreased frequencies correlated with the concentration of contaminant metals in the sediments $(\mathrm{Cd}, \mathrm{Cu}, \mathrm{Pb}, \mathrm{Mn}$ and $\mathrm{Zn}$ ). The second (shown by 15 , mostly less common crustacean species) revealed the frequencies of species to be correlated with particle size characteristics. We conclude that both contaminant metals and sediment particle size have substantial controlling effects on the community structure of this epibenthic seagrass fauna as well as that due to seagrass habitat. The contaminant metals had more effect on fishes than crustaceans of the study area, and there is little evidence of exploitation of the contaminated area by opportunistic epibenthic species.
\end{abstract}

\section{INTRODUCTION}

Few studies have attempted to examine the ecological effects of trace metals in the marine environment. Some have used large scale (Grice et al., 1977) artificial enclosures (CEPEX experiments) to test the ecological effects of selected metals but these are usually restricted to examination of planktonic organisms and food webs. Field studies of polluted sites ( e. g. Halcrow et al., 1973) are complicated by the presence of numerous pollutants in the effluent, each of which may have different environmental behaviour, magnitude and sites of effect. The effects of these materials (commonly pesticides, organic industrial wastes, suspended solids, nutrients) cannot be simply isolated from those of trace metals and must be the sum of effects of all such pollutants. Thus conclusions drawn from such studies are highly site-specific and cannot be extrapolated to other field situations.
The need for field, as opposed to laboratory, ecological studies of the effects of trace metals has been widely identified (e. g. Waldichuck, 1973; Cole, 1979) yet recent work has been mainly concerned with shortterm toxicity or bioaccumulation of metals (reviewed by Phillips, 1977). The ecological effects of trace metals are poorly understood, with little information available for metals other than mercury (Bryan, 1976).

The present study examines the community structure of the epibenthic vagile seagrass fauna near a large lead smelter. The smelter is located in a rural environment, and there are no other industries nearby. Since 1939 most of the liquid effluents from the smelter have been directed to First Creek, which opens into Spencer Gulf about $4 \mathrm{~km}$ northwest of the smelter works. The Gulf sediments near the outfall of First Creek are contaminated with $\mathrm{Cd}, \mathrm{Cu}, \mathrm{Mn}, \mathrm{Pb}$ and $\mathrm{Zn}$ (Ward and Young, 1981). The outfall of First Creek forms a point source for these metals and their concentrations in the 
sediments decreases with increasing distance from First Creek (exept for Cd). Four major shallow water habitats were identified on the basis of depth and floral cover (Ward and Young, 1981) These habitats form contiguous zones parallel to the shore and are continuous throughout and adjacent to the study area. Despite the high concentrations of metals in the sediments near First Creek the distribution of the seagrasses appears to be unaffected, and all appear healthy and vigorous. Previous studies (Young and Wadley, 1979) have shown that species composition and richness of epibenthic vagile fauna from an Australian seagrass area may vary with depth, seagrass species and water temperature and salinity. The salinity of Spencer Gulf in the study area is high (40 to $47 \%$ ) and relatively homogenous but varies seasonally (Anon, 1980; unpubl. own data). Temperature variations are related mainly to depth (unpubl. own data).

The unique characteristics of this area - a large isolated lead smelter and an homogenous marine environment - have enabled us to investigate the faunal assemblages in each of the four major habitats, and to study any differences that may relate to the trace metal content of the sediments described by Ward and Young (1981). We avoid the use of indices of diversity in our analysis of the community because of the attendant theoretical drawbacks and because they are of little practical value in assessing subtle effects of pollutants on faunal assemblages in coastal systems (Heck, 1976).

\section{MATERIALS AND METHODS}

Three transects were established perpendicular to the coast each passing from the shoreline towards deeper water. Transect A commenced near the mouth of First Creek, which carried the liquid effluent from the smelter to Spencer Gulf. Transects B and C were established 8 and $16 \mathrm{~km}$ south west respectively (Fig. 1). On each transect 4 sites were established, each centrally situated within the predominant habitat type (details of depths and habitats may be found in Ward and Young, 1981). Each site was characterised by its transect and site number, thus $\mathrm{A} 1, \mathrm{~B} 1$ and $\mathrm{C} 1$ were the intertidal unvegetated sites on Transects $A, B$ and $C_{\text {; }}$ A2 B2 and C2 were sites on intertidal Zostera mucronata, and so on. The concentrations of contaminant metals in the sediments and the dominant floral species at each of the sites (from Ward and Young, 1981) are given in Table 1 . The epibenthic vagile fauna at each site was sampled at high tide using as sampling gear a $1 \mathrm{~m}$ roller beam trawl with $2 \mathrm{~mm}$ mesh body and $1 \mathrm{~mm}$ mesh cod end. The trawl was towed between markers for $50 \mathrm{~m}$ at $0.04 \mathrm{~m} \mathrm{~s}^{-1}$; after each haul the catch was collected and preserved for identifica-

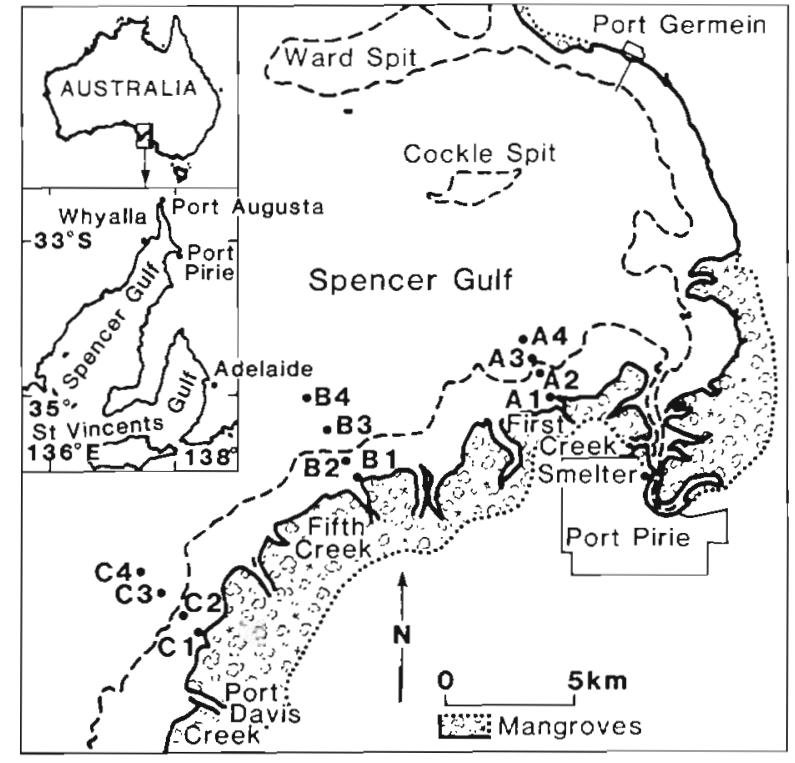

Fig. 1. Location of sites in Port Pirie study area

Table 1. Contaminant trace metals in Port Pirie sediments ( $\mu \mathrm{g} \mathrm{g}^{-1}$ dry wt., mean of triplicate samples)

\begin{tabular}{|c|c|c|c|c|}
\hline Site & Seagrass & $\begin{array}{c}\text { Transect } \\
\text { A }\end{array}$ & $\begin{array}{c}\text { Transect } \\
\text { B }\end{array}$ & $\begin{array}{c}\text { Transect } \\
\text { C }\end{array}$ \\
\hline & & & $\mathrm{Zn}$ & \\
\hline 1 & Bare & 16,667 & 32 & 11 \\
\hline 2 & Zostera mucronata & 7,283 & 359 & 38 \\
\hline 3 & Posidonia australis & 1,300 & 151 & 32 \\
\hline \multirow[t]{2}{*}{4} & Posidonia sinuosa & 631 & 109 & 15 \\
\hline & & & $\mathrm{Pb}$ & \\
\hline 1 & Bare & 5,270 & 6 & 3 \\
\hline 2 & Zostera mucronata & 2,630 & 35 & 9 \\
\hline 3 & Posidonia australis & 312 & 22 & 6 \\
\hline \multirow[t]{2}{*}{4} & Posidonia sinuosa & 156 & 18 & 2 \\
\hline & & & $\mathrm{Mn}$ & \\
\hline 1 & Bare & 1,227 & 189 & 168 \\
\hline 2 & Zostera mucronata & 378 & 106 & 83 \\
\hline 3 & Posidonia australis & 176 & 98 & 88 \\
\hline \multirow[t]{2}{*}{4} & Posidonia sinuosa & 143 & 87 & 85 \\
\hline & & & $\mathrm{Cu}$ & \\
\hline 1 & Ваге & 122 & 4 & 6 \\
\hline 2 & Zostera mucronata & 31 & 7 & 6 \\
\hline 3 & Posidonia australis & 8 & 4 & 4 \\
\hline \multirow[t]{2}{*}{4} & Posidonia sinuosa & 8 & 3 & 3 \\
\hline & & & $\mathrm{Cd}$ & \\
\hline 1 & Bare & 169 & 0.6 & $<0.2$ \\
\hline 2 & Zostera mucronata & 267 & 2.9 & $<0.2$ \\
\hline 3 & Posidonia australis & 22.5 & 1.5 & $<0.2$ \\
\hline 4 & Posidonia sinuosa & 9.7 & 1.1 & $<0.2$ \\
\hline
\end{tabular}

tion at the laboratory. Full details of the sampling method may be found in Young and Wadley (1979).

Each site was sampled in triplicate on 3 occasions: 
(1) during the day in winter; (2) during the night in winter ( 7 th to 16th August, 1979); (3) during the night in summer (3rd to 5th March, 1980). The only missing samples occurred at $\mathrm{C} 1$ during winter when samples could not be collected at night because of bad weather.

With this sampling strategy the effect of 4 sites, 3 transects and 3 times could be investigated by 3 -way analysis of variance, and interactions between the three main factors examined. The factor relating to contaminant metals was that of transect. It was expected that differences between Sites 1 to 4 and sampling times should occur naturally. However, the null hypothesis of no transect difference would predict that site or time differences should be the same on all 3 transects; if a transect effect or transect interaction occurred this would be evidence for the influence of the trace metal concentrations, particularly if the order of difference passed along the gradient Transect $A$, Transect $B$ to Transect $C$ in the same manner as the gradient of metals in sediments (Ward and Young, 1981).

Previous studies have shown that the species richness of seagrass fauna is binomially distributed (Young, 1981), therefore species richness counts (number of species per sample) were examined by analysis of variance after transformation to square roots to homogenize the variance.

The problems associated with investigating the distribution of species composition were resolved by the use of a combination of classification and ordination procedures. The samples were first classified by the program Multbet (Milne, 1976) using, as attributes, the presence or absence of all species present in the whole collection (106). Multbet is a polythetic agglomerative program providing an information statistic classification of binary data. The coherency of replicates was then tested by the methods of Sandland and Young $(1979 a, b)$ and if consistency between replicates in the collection was observed, the triplicates were then pooled delegating a frequency value between 0 and 3 for each species. This pooling was considered necessary to minimise the variance in this heterogeneous collection. The pooled samples were then classified using the frequency data of the 106 taxa by the program Cenperc (Milne, 1976). This program is a polythetic agglomerative program which provides an information statistic classification of frequency data. The particular algorithm used treats the frequencies of all species as a multistate variable. A principle co-ordinate analysis was then made on the intersite dissimilarity matrix (program Gower) producing linear combinations of scores for each sample on each eigenvector. Those scores reflected each major dissimilarity gradient in the collection and the efficiency of the ordination in extracting major changes in community com- position was then checked by comparison with the classification. The 4 major trends (shown by the scores of Eigenvectors I to IV) were then subjected to analysis of variance to detect which patterns of dissimilarity, if any, related to sites, time or transects. Finally, the diagnostic program Gowecor (Milne, 1976) was used to correlate the sample values of the original variables (species frequencies) with those of each set of eigenvectors to determine the identity of the groups of species best reflecting each dissimilarity gradient.

\section{RESULTS}

\section{Species Richness}

A total of 106 taxa were delineated, the majority of which were identified to species level. The analysis of variance of species richness (number of species per sample) was significant for sites, times and transects, but the interaction terms sites $\mathrm{x}$ times, transects $\mathrm{x}$ sites and sites $\mathrm{x}$ time $\mathrm{x}$ transects were also significant. From this interaction it is concluded that species richness varied between transects, as well as between sites and times, but its effect was not uniform at all sites, nor at all times at these sites.

Examination of the means of transformed species counts for each set of replicates by least significant difference enabled us to detect the nature of these interactions (Table 2).

On all transects, at all sampling times, samples from Site 1 had less species than all of those from any other site on its particular transect. This difference was significant for all transects and times except in the winter day samples when $\mathrm{A} 1$ and $\mathrm{C} 1$ were not significantly different from $\mathrm{A} 2$ and $\mathrm{C} 2$ respectively and in the winter night samples when A1 was not significantly different from A2 or A3. At Sites 1 the number of species did not differ significantly either between transects within time, or with time within transects. Sites 1 are therefore characterised by low species counts and reduced variability.

In contrast, Sites 2 usually displayed significant changes in species richness between transects on all 3 sampling occasions, caused by fewer species at A2 compared with B2 and C2. Sites B2 and C2 did not differ significantly on any sampling occasion. The samples taken at $\mathrm{A} 2$ in winter (day and night) were particularly depauperate, approaching the low numbers of A1.

The species richness of Sites 3 showed a similar change with transect to that at Sites 2. Progressively more species occurred in sampling from A3 to B3 to C3 on each sampling occasion. More species were present at night in summer than in winter on each transect and 
Table 2. Means of triplicate samples of species richness ( $\sqrt{\text { no. of species per sample }})$

\begin{tabular}{|c|c|c|c|c|c|c|c|c|c|}
\hline \multirow{2}{*}{ Site } & \multirow{2}{*}{\multicolumn{3}{|c|}{$\begin{array}{c}\text { Winter day samples } \\
\text { Transect }\end{array}$}} & \multicolumn{3}{|c|}{$\begin{array}{c}\text { Winter night samples } \\
\text { Transect }\end{array}$} & \multicolumn{3}{|c|}{$\begin{array}{c}\text { Summer night samples } \\
\text { Transect }\end{array}$} \\
\hline & A & & & & & C & A & $B$ & C \\
\hline 1 & 1.520 & 1.626 & 2.000 & 1.821 & 2.394 & M & 2.139 & 2.150 & 2.580 \\
\hline 2 & 1.989 & 3.048 & 2.759 & 2.580 & 3.635 & 3.644 & 3.051 & 3.357 & 3.847 \\
\hline 3 & 2.444 & 3.000 & 3.914 & 2.426 & 4.269 & 5.596 & 4.532 & 5.799 & 5.911 \\
\hline 4 & 2.378 & 2.520 & 2.782 & 4.000 & 3.651 & 5.000 & 4.988 & 5.255 & 5.016 \\
\hline \multicolumn{10}{|c|}{ Lsd $P \leq 0.01 ; 0.775$} \\
\hline
\end{tabular}

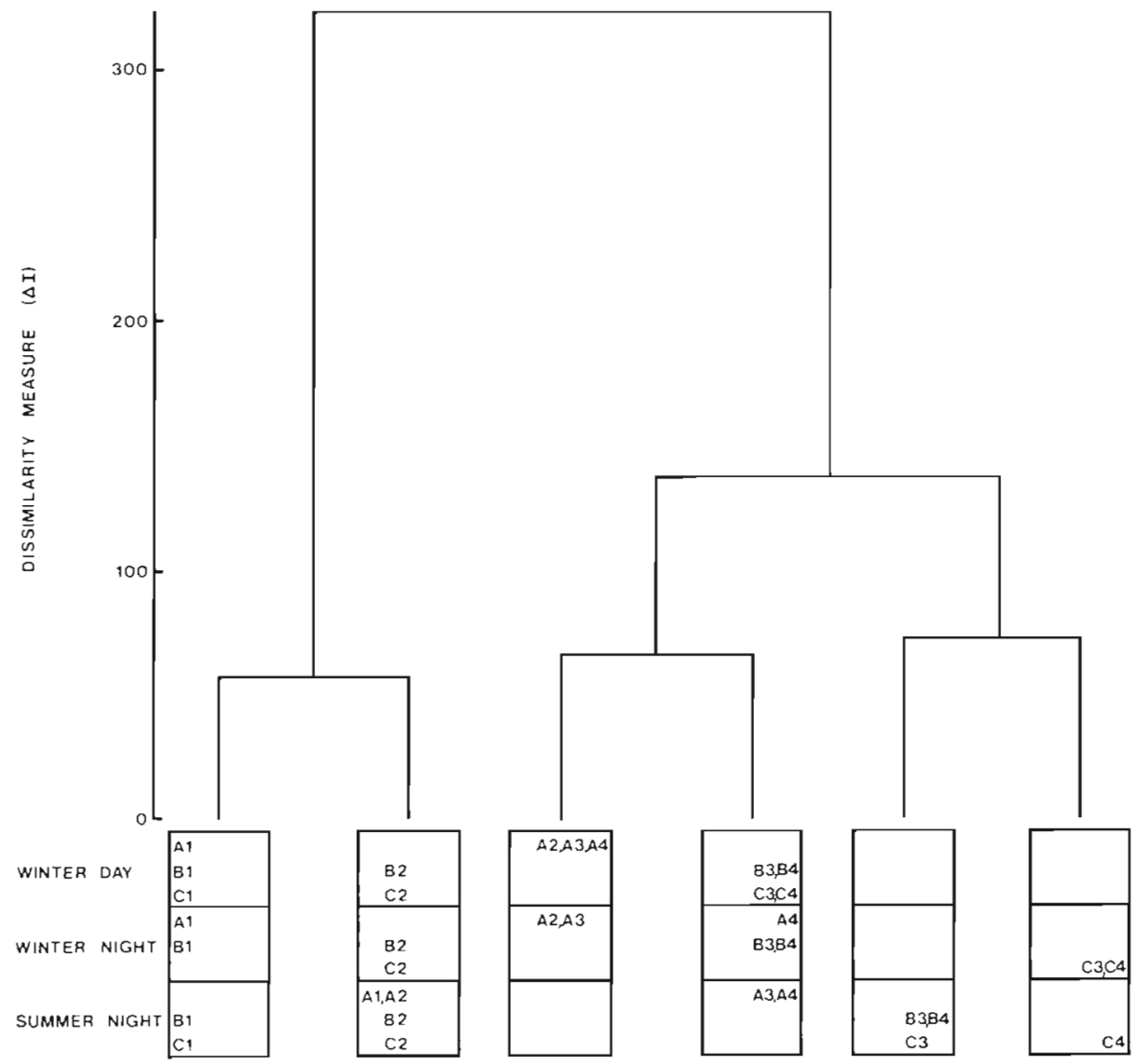

Fig. 2. Classification of samples

least were present during the day in winter. Greatest temporal changes in these sites occured at B3 where the low winter day counts did not differ from those at A3 whilst the high summer night counts did not differ from those at $\mathrm{C} 3$. At Sites 4 more species were again collected progressively from $\mathrm{A} 4$ to $\mathrm{B} 4$ to $\mathrm{C} 4$ but the only occasion that the differences were significant was in the winter night samples when $\mathrm{C} 4$ counts were significantly higher than at A4 and B4. More species were present at night in summer than in winter and least during the day in winter, with greatest variability at B4.

\section{Species Composition and Abundance}

The initial Multbet classification showed significant clustering of replicates to the 15 group level. It was therefore considered that replicates were sufficiently similar to be pooled for further analysis without loss of critical information. The Cenperc classification (Fig. 2) clearly extracted differences between sites, transects and time. However, the pattern of branching of the dendrogram indicated that the three factors interacted to give a complex picture. At the two-group level; all except two samples from Sites 1 and 2 were separated 
from those of Sites 3 and 4 . On the next subdivision of this group of Sites 1 and 2 all but one sample from Site 1 separated from the Site 2 samples, showing little transect influence at this level. In the second group site, time and transect influences were mixed. The group split at a high level of the hierarchy and at this level the classification separated the winter and summer night samples of $\mathrm{C} 3$ and $\mathrm{C} 4$, placing with them the summer night samples from B3 and B4, thus discriminating between transects, but in a complicated way. The third group consisted of the remaining samples from Sites 3 and 4 together with day and night winter samples from A2. On subdivision, these 2 samples from A2 grouped together with winter day and night samples from A3 and winter day samples from A4. Transect influence thus was apparent but again discriminating in a complicated way. The major difference between the fauna of Sites 1 and 2 and that of Sites 3 and 4 dominate the analysis but a strong interaction between time and transect combine to give a confused result at lower levels of the classification.

The ordination recovered the major patterns revealed by the classification, and by separating the differences into orthogonal gradients clarified the relative importance of the transect differences implied in the classification. The presence of so many interactions however, suggests that the ordination should be interpreted with care. Only $52.6 \%$ of the variance was extracted by the first 4 eigenvectors $(26.4,11.5,8.5,6.3$ respectively), suggesting that either many distributional patterns occur within the large number of species involved, or that the restricted numbers of many species require more extensive sampling to adequately assess their distribution.

Despite these reservations, the analysis of variance showed significant differences between sample scores for these first 4 eigenvectors (Table 3 ). As expected, at least one interaction term was significant on each

Table 3. Significance of F-ratios from analyses of variance

\begin{tabular}{|c|c|c|c|c|}
\hline \multirow{2}{*}{ Factor } & \multicolumn{4}{|c|}{ Eigenvectors } \\
\hline & $\overline{\mathrm{I}}$ & $\overline{\mathrm{II}}$ & $\underline{\overline{\mathrm{III}}}$ & $\underline{\mathrm{IV}}$ \\
\hline Transect & ns & $\cdots$ & ns & - \\
\hline Time & $\cdots$ & ns & $\cdots$ & $\cdots$ \\
\hline Site & .. & • & ns & ns \\
\hline Transect $\times$ time & ns & ns & $\cdot$ & $\cdot$ \\
\hline Transect $\times$ site & $\cdot$ & $\cdot$ & $\cdot$ & ns \\
\hline Site $\times$ time & * & ns & ns & ns \\
\hline Transect $\times$ site $\times$ time & - & - & - & - \\
\hline \multicolumn{5}{|c|}{ 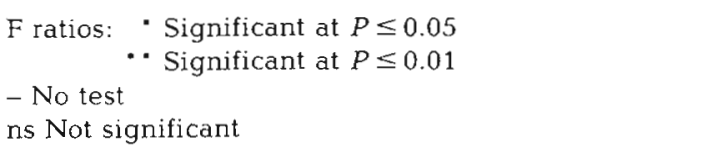 } \\
\hline
\end{tabular}

vector, but examination of the plotted scores showed that the ordination extracted all the principal faunal differences revealed in the classification, and enabled them to be related to environmental differences between sites.
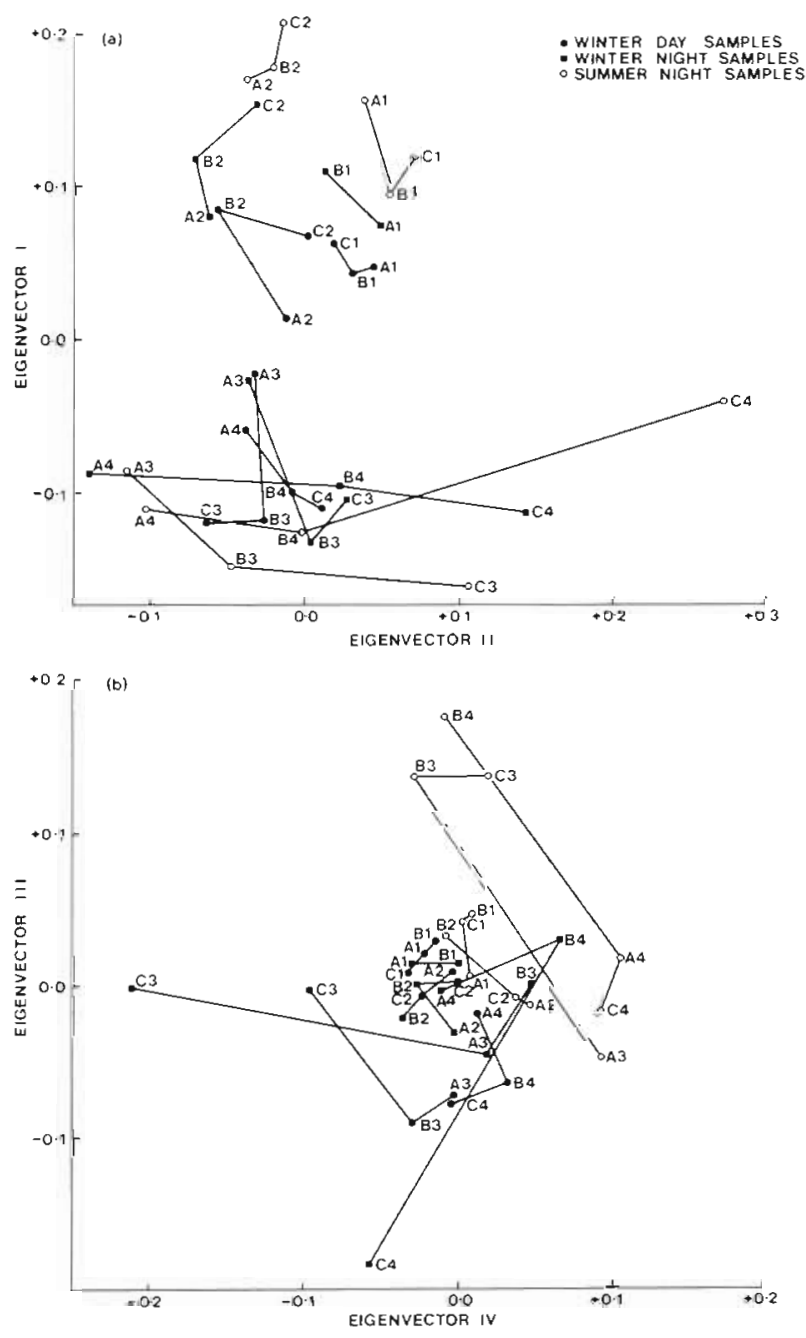

Fig. 3. Principal Coordinate Analysis. (a) Scores of samples on Eigenvector I and $I_{;}$(b) scores of samples on Eigenvectors III and IV

The first eigenvector retrieved the major difference in the classification shown between Sites 1 and 2 and Sites 3 and 4 (Fig. 3a). This eigenvector also demonstrated that - although little consistent transect difference was present at Sites 1 - differences occurred at all other sites across transects, though varying in degree according to the time of sampling. These differences, consisting of a progressive change from Transect $\mathrm{A}$ to $\mathrm{B}$ and $C$ at Sites 2, 3 and 4, were present to some degree on all sampling occasions. In all samples from Sites 2 and the summer samples at Site 4 , scores rose from Transect $A$ to $C$, whereas those from Site 3 and the Site 
4 winter samples fell. This produced a gradient of change in which Sites 2 became progressively less similar to Sites 3 and 4 in passing from Transect $A$ to $C$. However, the summer samples from Sites 4 became more similar to Sites 2 in passing from Transect A to C. The 20 species best correlated to this pattern are all relatively abundant and include all except one of the species diagnostic for the classification of differences between Sites 1 and 2 and Sites 3 and 4 (Table 4). The frequency and mean abundance of most of these species increase at Sites 3 and 4 , but a few increase at
Sites 1 and 2. The majority of these species, at most sampling times, became less frequent and less abundant in sites passing from Transect $C$ to $A$. This produced a low species richness at Transect $A$ and concomitantly an overall faunal similarity between sites at this Transect (also revealed in the classification Fig. 2). However, the summer samples from Sites 4 were exceptional in that these species were generally less frequent and less abundant at $\mathrm{C} 4$ than at $\mathrm{A} 4$ or $\mathrm{B} 4$.

The differences shown by Eigenvector $\overline{\mathrm{II}}$ (Fig. 3a; Table 4) suggest that in summer this loss of abundant

Table 4. Groups of species best correlated to the faunal differences shown by the ordination

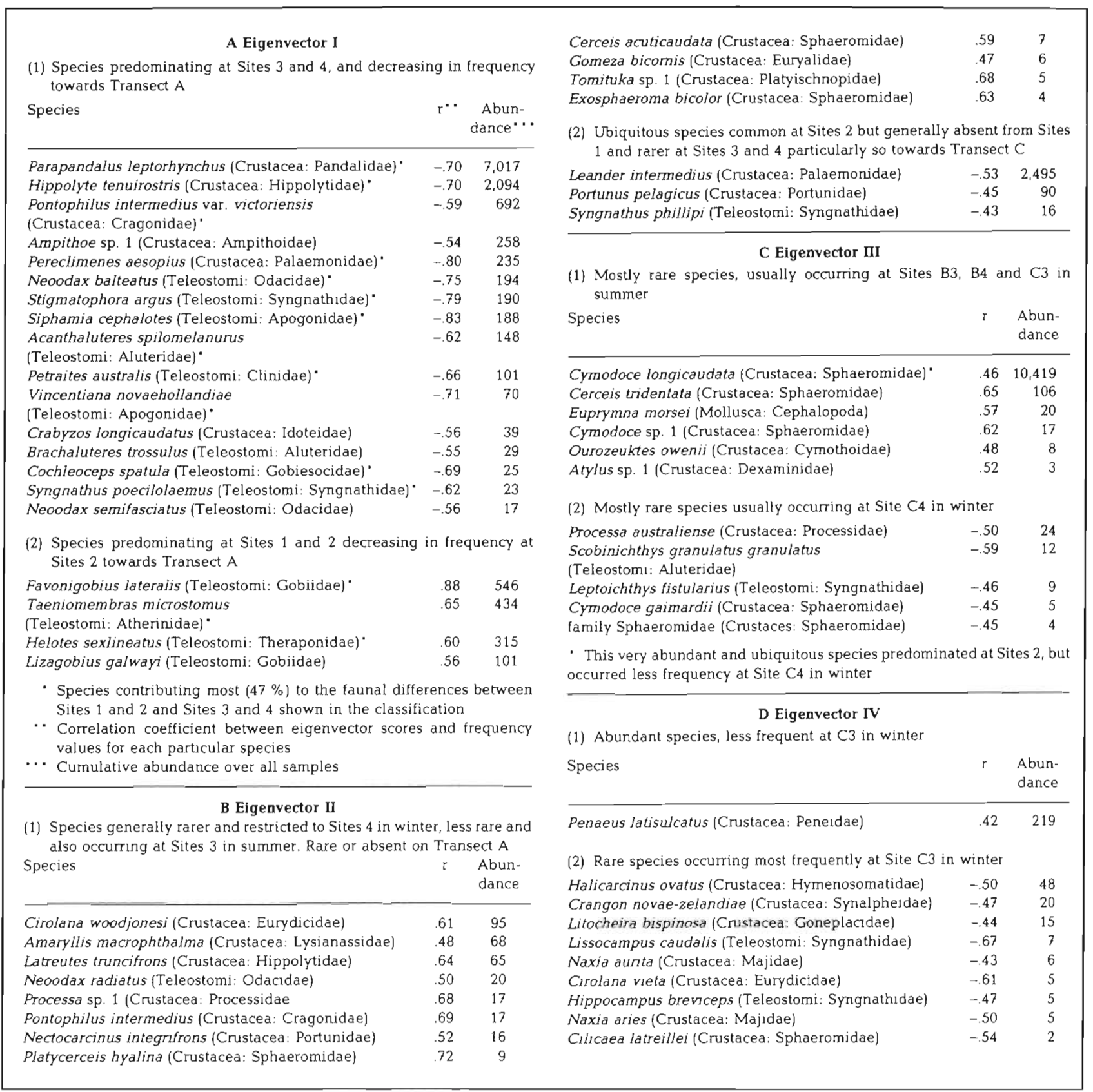


species at $\mathrm{C} 4$ was compensated by the occurrence of a group of species with distributions different from those of the species associated with the primary pattern described by Eigenvector $\overline{\bar{I}}$. The distributions of this new group of species results in the separation of Sites 1 from Sites 2 on the basis of eigenvector scores (consistent with the differences observed in the classification), and in the partitioning of sites in a gradient from $A$ to $B$ to $C$ in all samples from Sites 4 and in the summer samples from Sites 3 (Fig. 3a). The frequencies and abundances of the 15 species positively correlated to this pattern (Eigenvector $\overline{\mathrm{II}}_{i}$ Table 4 ) showed that these species were generally less frequent and with low abundarices in the study area. Many of these species were absent in winter or restricted to Sites 4 . In summer they occurred much more often and extended their range to include Sites 3 . In both seasons their frequencies and abundances declined from Transect $C$ to Transect $\mathrm{A}$. Three species were negatively correlated to this pattern and, by occurring rarely at Site 1. are largely responsible for the differences between Sites 1 and 2 shown by the scores of Eigenvector II (Table 4).

The scores of Eigenvectors $\overline{I I I}$ and $\overline{I V}$ emphasized differences at Sites 3 and 4 . These discriminated the winter night samples at $\mathrm{C} 3$ and $\mathrm{C} 4$ from the summer night samples at B3, B4, and C3 (Fig. 3b). These differences reflect the partitioning of these samples in the classification (Fig. 2), and examination of the species best correlated to the 2 eigenvectors showed that these differences are due largely to (a) infrequent species, occurring predominantly at sites B3, B4, and C3 in summer, (b) infrequent species, occurring principally at site $\mathrm{C} 3$ in winter (Table 4).

Fifty species failed to correlate to any patterns demonstrated by the ordination (Table 5); 23 occurred only once, the remaining 27 were rare species comprising 15 crustaceans, 11 fish and 1 mollusc. Their failure to associate with the 4 main patterns described indicates that their distributions change in some other manner, or that insufficient data was collected to discern a pattern. Although they may not be affected by sediment trace metals or particle size this cannot be concluded from the present study.

\section{DISCUSSION}

The 4 sites on each transect examined in this study ranged from mid-intertidal bare mud through intertidal seagrasses to subtidal seagrassed sites. Each of the 4 sites contained sets of epibenthic species that did not overlap with the other sites, as well as more generally distributed epibenthic species that ranged over 2 or more sites on a transect. This resulted in greatest faunal differences between the intertidal and the subtidal sites. This is not surprising, given the substantial physical differences between such sites. Such depthrelated differences have been previously described in seagrasses (Young and Wadley, 1979) and differences between seagrass meadows are known to persist through the year (Young, 1981). What is noteworthy, however, is that the differences observed between the intertidal and subtidal fauna increased progressively from Transects $A$ to $B$ and $C$. Thus Transect $A$ had the most similar fauna across all four sites while Transect $C$ had the least similar fauna across sites. This modification ot the primary "between site" differences, although insufficient to prevent discrimination of the intertidal from the subtidal fauna, nevertheless masked any potential differences between the fauna of Sites 3 and 4 . As 2 eigenvectors were required to display this variability between the two deeper sites, it occurred in at least 2 independent ways.

The major environmental variation between transects at Sites 3 and 4 pertained to trace metal concentrations and sediment particle size. These have previously been shown to vary independently of each other across these study sites (Ward and Young, 1981). Computation of the correlation coefficient between the concentrations of each trace metal and the eigenvector scores of samples from Sites 3 and 4 demonstrated that the variation described by Eigenvector $\bar{I}$ at these sites was significantly correlated to the sediment concentrations of several trace metals (Table 6), but only in winter samples.

By contrast, the variation at Sites 3 and 4 shown by Eigenvector II was correlated to $\mathrm{Cu}$, total organic carbon (TOC) and to sediment particle size, principally in the summer samples. This faunal variability was attributable mainly to 13 crustaceans and 2 fishes. These occurred principally in summer and produced the relationship at this time. All the crustaceans live close to the sediment surface and some (e. g. Pontophilus intermedius) are shallow burrowers. Most showed greater frequencies as the proportion of fine sediments decreased, however three ubiquitous species (Leander intermedius, Portunus pelagicus and Syngnathus phillipi) occured more frequently at Transect $A$ when caught at Sites 3 and 4 , suggesting that these species preferred the finer particle sizes there. Although $\mathrm{Cu}$ was also correlated to this pattern, its distribution is also correlated to TOC, clay and sand in this study area (Ward and Young, 1981), and its correlation with the faunal change most probably reflects this association rather than a direct faunal/metal relationship.

The faunal variability shown by Eigenvector $\bar{I}$ at Sites 3 and 4 and correlated with trace metal concentrations was mostly due to a reduction in frequency 
Table 5. Distribution and total abundance of species

(a) Species restricted to Sites 3 and 4

\begin{tabular}{|c|c|c|c|c|c|c|c|}
\hline \multicolumn{8}{|c|}{ (a) Species restricted to Sites 3 and 4} \\
\hline \multirow{3}{*}{ 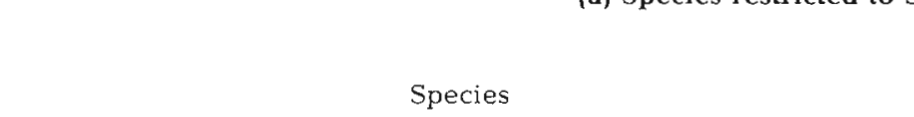 } & \multirow[b]{3}{*}{ Abundance } & \multicolumn{6}{|c|}{ Distribution } \\
\hline & & \multicolumn{3}{|c|}{ Sites 3} & \multicolumn{3}{|c|}{ Sites 4} \\
\hline & & A & B & C & A & B & C \\
\hline Family Eusiridae n. gen. (Crustacea: Eusiridae) & 54 & & & + & & & + \\
\hline Trigonoplax unguiformis longirostris (Crustacea: Hymenosomatidae) & 8 & & + & + & + & + & \\
\hline Cristiceps australis (Teleostomi: Clinidae) & 5 & + & + & & + & & \\
\hline Atylus homochir (Crustacea: Dexaminidae) & 5 & & + & & + & & \\
\hline Ophiclinops pardalis (Teleostomi: Ophiclinidae) & 4 & + & + & & & & \\
\hline Platycephalus haackei (Teleostomi: Platycephalidae) & 4 & & + & + & & + & \\
\hline Aetapcus vincenti (Teleostomi: Pataecidae) & 2 & & + & + & & & \\
\hline Euidotea caeruleotincta (Crustacea: Idoteidae) & 6 & & & + & & & \\
\hline Paradexamine sp. 1 (Crustacea: Dexaminidae) & 3 & & & + & & & \\
\hline Aploactisoma milesii milesii (Teleostomi: Aploactidae) & 1 & & & + & & & \\
\hline Atopomycterus nichthemerus (Teleostomi: Diodontidae) & 1 & & & + & & & \\
\hline Cnidoglanis macrocephalus (Teleostomi: Plotosidae) & 1 & & & + & & & \\
\hline Paracilicaea hamata (Crustacea: Sphaeromidae) & 1 & & & + & & & \\
\hline Shrimp - unknown family (Crustacea) & 1 & & & + & & & \\
\hline Alpheus sp. 2 (Crustacea: Alpheidae) & 1 & & & + & & & \\
\hline Taeniomembras tamarensis (Teleostomi: Atherinidae) & 1 & & & + & & & + \\
\hline Family Eusiridae (Crustacea: Eusiridae) & 22 & & & & & & + \\
\hline Paraoediceroides sp. 1 (Oedicerotidae) & 1 & & & & & & + \\
\hline Hippomendron sp. 1 (Crustacea: Lysianassidae) & 1 & & & & & & + \\
\hline Octopus flindersi (Mollusca: Cephalopoda) & 1 & & & & & & + \\
\hline Codonophilus imbricatus (Crustacea: Cymothoidae) & 1 & & & & & & + \\
\hline Siphonognathus argyrophanes (Teleostomi: Odacidae) & 1 & & & & & & + \\
\hline Fish - unknown family (Teleostomi) & 1 & & & & & & + \\
\hline Synischia levidensis (Crustacea: Idoteidae) & 1 & & & & & & + \\
\hline Engraulis australis antipodum (Teleostomi: Engraulidae) & 1 & & + & & & & \\
\hline Halicarcinus rostratus (Crustacea: Hymenosomatidae) & 1 & & & & & + & \\
\hline Aracana ornata (Teleostomi: Ostraciontidae) & 1 & + & & & & & \\
\hline Isopoda - unknown family (Crustacea) & 1 & + & & & & & \\
\hline Leander serenus (Crustacea: Palaemonidae) & 1 & + & & & & & \\
\hline Callogobius mucosus (Teleostomi: Gobiidae) & 1 & & & & + & & \\
\hline \multicolumn{8}{|c|}{ (b) Species restricted to Sites 1 and 2} \\
\hline Syngnathus vercoi (Teleostomi: Syngnathidae) & 23 & + & & & + & + & + \\
\hline Eriocheir spinosus (Crustacea: Grapsidae) & 9 & & & & + & + & \\
\hline Philyra laevis (Crustacea: Leucosiidae) & 7 & & & & & + & + \\
\hline Nesogobius hinsbyi (Teleostomi: Gobiidae) & 5 & & + & & & + & \\
\hline Apseudes sp. 1 (Crustacea: Apseudidae) & 5 & & & & & + & + \\
\hline Zeuxo sp. 1 (Crustacea: Tanaidae) & 3 & & & & & & + \\
\hline Pseudorhombus arsius (Teleostomi: Bothidae) & 2 & & + & & & & + \\
\hline Sillaginodes punctatus (Teleostomi: Sillaginidae) & 2 & & & & + & & + \\
\hline Leptonotus costatus (Teleostomi: Syngnathidae) & 2 & + & & & & & \\
\hline Alpheus sp. 1 (Crustacea: Alpheidae) & 1 & & & & + & & \\
\hline Cerceis ovata (Crustacea: Sphaeromidae) & 1 & & + & & & & \\
\hline Euidotea stricta (Crustacea: Idoteidae) & 1 & & & & & + & \\
\hline \multicolumn{8}{|c|}{ (c) Species without obvious distribution restrictions } \\
\hline Cymadusa filosa (Crustacea: Amphithoidae) & 554 & & & & & & \\
\hline Idiosepius notoides (Mollusca: Cephalopoda) & 358 & & & & & & \\
\hline Gymnapistes marmoratus (Teleostomi: Scorpaenidae) & 246 & & & & & & \\
\hline Leucothoe sp. 1 (Crustacea: Leucothoidae) & 12 & & & & & & \\
\hline Euidotea peronii (Crustacea: Idoteidae) & 6 & & & & & & \\
\hline Lembos sp. 1 (Crustacea: Aoridae) & 5 & & & & & & \\
\hline Hemiramphus melanochir (Teleostomi: Hemiramphidae) & 3 & & & & & & \\
\hline Family Ampithoidae (Crustacea: Amphithoidae) & 2 & & & & & & \\
\hline
\end{tabular}


Table 6. Coefficients from the correlation of eigenvector scores at A3, A4, B3, B4, C3 and C4 against sediment parameters at those sites. (After Ward and Young, 1981)

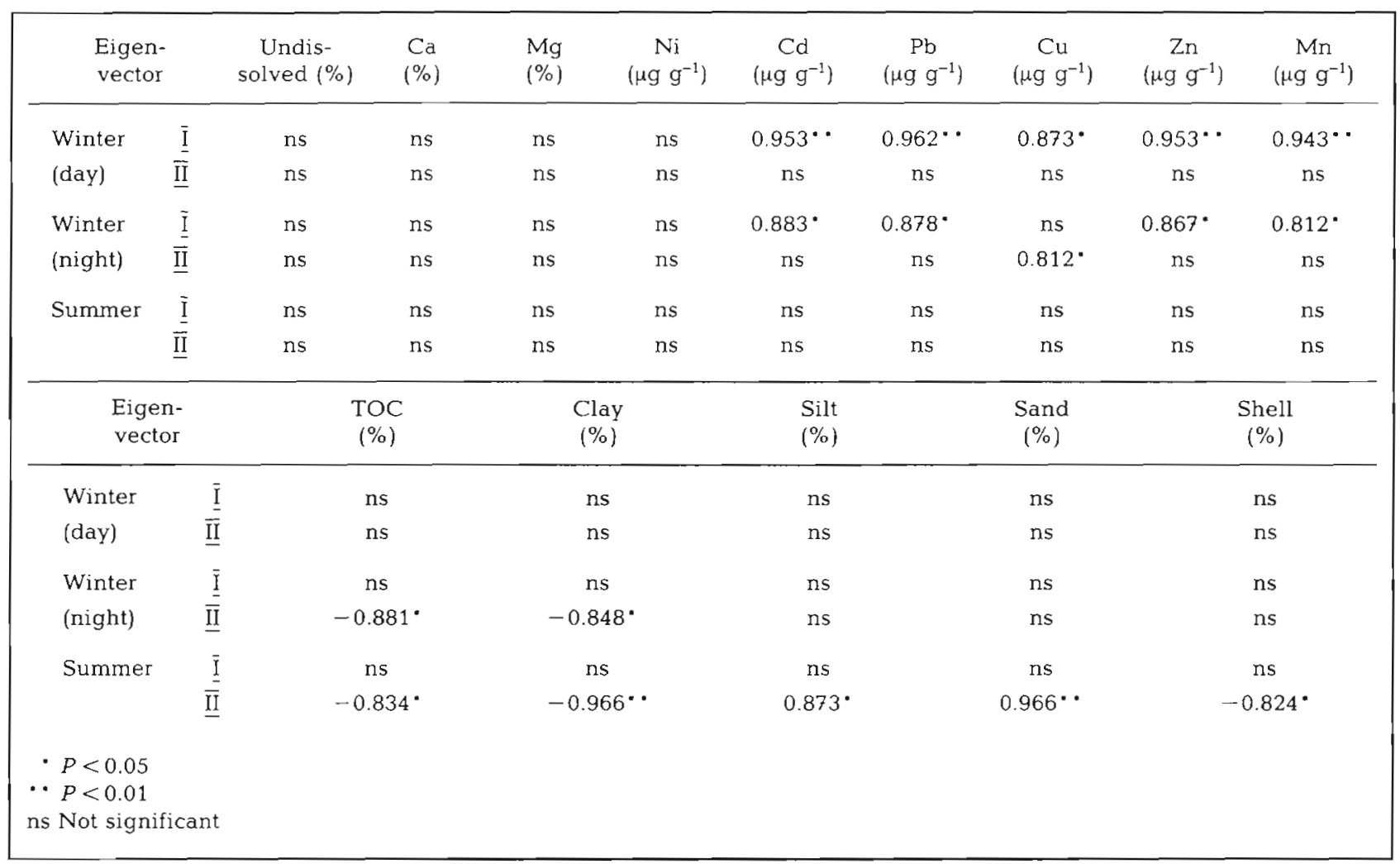

(and also abundance) of 14 fish species and six crustaceans with increased sediment concentrations of the contaminant metals. Four of these fish species predominated in the Zostera mucronata habitat (Site 2) these were Favonigobius lateralis, Lizagobius galwayi, Taeniomembras microstomus, and Helotes sexlineatus. However, when they occurred in Posidonia australis or $P$. sinuosa (Sites 3 and 4), they also showed the decline towards sediments with high metal concentrations. All these species occurred frequently with high abundances, comprising 14 of the 18 most abundant fish, and 6 of the 23 most abundant crustaceans (Table 4). Since the overall ratio of fish to crustaceans in the collection was $1: 2$, this suggests that the fish species are more susceptible than the crustaceans to increases in trace metal concentrations.

These fishes are mainly carnivores, with the exception of 3 common species Acanthaluteres spilomelanurus, Syngnathus poecilolaemus and Helotes sexlineatus, the first 2 of which are omnivores (Scott, 1981) while the latter is an algal hervibore (unpubl. own data). Thus it is apparent that the gradient of effects of the metals is not restricted to fishes of any one general feeding category. The presence only in winter of this metal-related faunal variability suggests a seasonally mediated toxicity. However, this could be equally well explained by the ingress, in summer, of new recruits from uncontaminated areas. Significant differences in body metal loads have been found for several species of the fish at Transect A (unpubl. own data), and it is probable that the observed faunal decline is caused by metal toxicity. The species of this group became less frequent and less abundant towards the contaminated seagrasses at Transect $A$ and it is clear that despite the consequent availability of the primary resources of shelter and food (Kikuchi, 1980; Robertson, 1980) at such sites, metal resistant, opportunistic epibenthic species exploit neither this contaminated area nor the seagrasses at Transect B where sediment concentrations of metals are much lower.

The loss of species ascribed here to the effects of trace metals is consistent with the effects of other pollutants on benthic fauna (Gray, 1979). However, such a reduction in species richness was not found in seagrass fauna affected by pulp mill effluent (Heck, 1976). This may be due to different modes of action of the contaminants, the metals producing a direct toxic effect, whilst the pulp mill effluent modified the habitat (Heck, 1976). Alternatively the difference may be due to the great range of metal concentrations in the sediments here. Possibly, in areas with slightly elevated metal concentrations, species abundance - but 
not richness - may decline, as was found by Heck (1976).

The sediment concentrations of $\mathrm{Cd}, \mathrm{Pb}$ and $\mathrm{Zn}$ at Transect $\mathrm{B}$, about $8 \mathrm{~km}$ from the primary source, were lower than those noted to have substantial sublethal effects (burrowing response) on the clam Macoma balthica (McGreer, 1979). The present study shows, however, that even at such levels the community structure responds holistically to the contaminants by a decrease in species richness, and reduced incidences and abundances of frequent species and as such is probably the best indicator of the effects of long term contamination by trace metals.

The 2 primary environmental gradients discussed here - contaminant trace metals $(\mathrm{Cd}, \mathrm{Cu}, \mathrm{Pb}, \mathrm{Mn}$ and $\mathrm{Zn}$ ) and sediment particle size - appear to exert substantial control over the community structure of the fauna of the contaminated area. The fauna here is extremely depauperate, with metals responsible for effects on the majority of the common fishes and on several of the most common crustaceans. In addition, the fine sediments of the contaminated area further restricts the distribution of a number of crustacean species. Since these epibenthic species are prey for many higher predators, including commercial fish species, squid, sharks, seabirds and dolphins, the contaminated area probably supports fewer species at all consumer trophic levels.

In this study sediment parameters have been used to explain the observed patterns of faunal distribution. Whilst the sediment metal concentrations are probably related to water column metal concentrations, it is not clear whether it is metals of the water or of the sediments that are mainly responsible for the observed effects. The effects of the metals could also be mediated partly through the disruption of normal ecological interactions (such as predator-prey relationships) although the existence of these effects has yet to be demonstrated. The contribution of direct metal toxicity to the overall pattern of metal effects in the study area is now being investigated and a series of field experiments designed to evaluate the direct toxicity of water metals to selected epibenthic species in the field is now underway.

Acknowledgements. This study was substantially funded by the International Lead Zinc Research Organization Inc. We are grateful for the assistance of $\mathrm{Mr} \mathrm{V}$ Neverauskas in field and laboratory work. Ms. A. Green, Mr. C. Horne and Mr. N. Holmes also assisted with field work. We thank the following for their assistance with the taxonomy: Dr. J. Glover, Dr W. Zeidler, South Australian Museum, Adelaide; Dr. J. Lowry, Australian Museum, Sydney; and Dr. C. Lu, National
Museum, Melbourne. Mr. W. Thomas, Port Pirie, S. A., kindly allowed us use of a storage shed near the study area.

\section{LITERATURE CITED}

Anonymous (1980). Redcliffe PToject, draft environmental effects statement. Dow Chemical (Aust.) Ltd., Adelaide, S. A. April 1980, p. 178

Bryan, G. W. (1976). Heavy metal contamination in the sea. In: Johnston, R. (ed.) Marine pollution. Academic Press, New York, pp. 185-302

Cole, H. A. (1979). Summing up: deficiencies and future needs. Phil. Trans. R. Soc. (Series B) 286: 625-633

Gray, J. S. (1979). Pollution induced changes in populations. Phil. Trans. R. Soc. (Series B) 286: 545-561

Grice, G. D., Reeve, M. R., Koeller, P., Menzel, D. W. (1977) The use of large volume, transparent, enclosed sea-surface water columns in the study of stress on plankton ecosystems. Helgoländer wiss. Merresunters. 30: 118-133

Halcrow, W., Mackay, D. W. Thornton, I. (1973). The distribution of trace metals and fauna in the Firth of Clyde in relation to the disposal of sewage sludge. J. mar. biol. Ass U. K. 53: 721-739

Heck, K. L., Jr. (1976). Community structure and the effects of pollution in seagrass meadows and adjacent habitats Mar. Biol. 35: 345-357

Kikuchi, T. (1980). Faunal relationships in temperate seagrass beds. In: Phillips, R. C., McRoy, C. P. (eds.) Handbook of seagrass biology. Garland Press, New York, pp. 153-172

McGreer, E. R. (1979). Sublethal effects of heavy metal contaminated sediments on the bivalve Macoma balthica (L.). Mar. Pollut. Bull. 10; 259-262

Milne, P. W. (1976). The Canberra programs and their accession. In: Williams, W. T. (ed.) Pattern analysis in agricultural science. CSIRO (Commonwealth Scientific and Industrial Research Organization), Melbourne, pp. $116-123$

Phillips, D. J. H. (1977). The use of biological indicator organisms to monitor trace metal pollution in marine and estuarine environments - a review. Environ. Pollut. 13: 281-318

Robertson, A. I. (1980). The structure and organization of an eelgrass fish fauna. Oecologia 47: 76-82

Sandland, R. L., Young, P. C. (1979a). Probabilistic tests and stopping rules associated with hierachical classification techniques. Aust. J. Ecol. 4: 399-406

Sandland, R. L., Young, P. C. (1979b). Tables of probabilities associated with the fission of replicate samples in classifications. Rep. Div. Fish. Oceanogr. C.S.I.R.O. Aust. 108

Scott, J. K. (1981). The seagrass fish fauna of Geographe Bay, Western Australia. J. R. Soc. West. Aust. 63: 97-102

Waldichuck, M. (1973). Trends in methodology for evaluation of effects of pollutants on marine organisms and ecosystems. CRC Crit. Rev. Envir. Control 3: 167-211

Ward, T. J., Young, P. C. (1981). Trace metal contamination of shallow marine sediments near a lead smelter, Spencer Gulf, South Australia. Aust. J. mar. Freshwat. Res. 32: $45-46$

Young, P. C. (1981). Temporal changes in the vagile epibenthic fauna of two seagrass meadows (Zostera capricorni and Posidonia australis). Mar. Ecol. Prog. Ser. 5: 91-102

Young, P. C., Wadley, V. A. (1979). Distribution of shallowwater epibenthic macrofauna in Moreton Bay, Queensland, Australia. Mar. Biol. 53: 83-97 